\title{
Effects on Brassica napus L. Yield and Yield Components of Super Absorbent Polymer under Different Irrigation Regimes
}

\author{
Alireza PIRZAD ${ }^{1 *}$, Mousa JAMALI ${ }^{2}$, Fahime SHOKRANI ${ }^{3}$ \\ ${ }^{I}$ Faculty of Agriculture, Department of Agronomy Urmia University, Urmia, Iran; a.pirzad@urmia.ac.ir (*correspondingauthor) \\ ${ }^{2}$ Faculty of Agriculture, Department of Agronomy, Payamenoor University, P. O. Box: 19395-3697, Tehran, Iran \\ ${ }^{3}$ Faculty of Agriculture, Department of Agronomy, Payamenoor University, P. O. Box: 19395-3697, Tehran, Iran
}

\begin{abstract}
For evaluation of the effects of super absorbent polymer under different irrigation regimes on the yield and yield components of Brassica napus L., a factorial experiment was carried out, based on randomized complete block design with four replicas. Treatments included super absorbent polymer $(0,1,2,3,4$ and $5 \mathrm{~g} / \mathrm{kg}$ soil) and induced drought stress (irrigation at 25,50 and $75 \mathrm{~mm}$ evaporation from class A pan). The experiment was conducted in pots with $5 \mathrm{~kg}$ of soil. Data analysis of variance showed the significant interaction effect between polymer and irrigation on the stem length, width and weight, the number of seeds per sheath, number of seeds per plant, the number of sterile and fertile sheath per plant, fertile sheath percentage (fertile sheath/ total sheath $\times 100$ ), 1000 seeds weight, seed weight per plant, sheath weight per plant and the number of total sheath. The present study revealed that indifferent from the applied amounts of the super absorbent polymer, in all cases the measured characters have been more affected by induced drought stress.
\end{abstract}

Keywords: 1000 seed weight, canola, evaporation pan, polymer, stress

\section{Introduction}

In many regions of the world, including Iran, water deficit stress is one of the most important factors that decrease agricultural crop production (Zahedi et al., 2009). Drought is the most significant factor restricting plant growth and crop productivity in the majority of agricultural fields of the world (Abedi and Pakniyat, 2010) and it negatively affects many plant processes, such as photosynthesis, transpiration, stomatal conductance, and metabolite accumulation (Ohashi et al., 2006).

Oil seed canola plant (Brassica napus L., rapeseed) is an important and worldwide agricultural crop grown primarily for its edible oil. This crop is mainly grown in rain fed areas, where water availability is one of the most important limiting factors affecting plant growth and development. Canola is generally considered to be more susceptible to drought. The yield is mainly affected by water shortages which occur during the stage from flowering to the end of the seed set (Din et al., 2011). The canola meal that remains after oil extraction is important as a protein source for the livestock feed industry (Jensen et al., 1996). Its oil is of premium quality with low erucic acid and glucosinolates contents. The yield of rapeseed is mainly affected by water shortages, which occur during the stage from flowering to the end of the seed set, because it is generally considered to be more susceptible to drought (Din et al., 2011).

The available water in soil is one of the most important factors of increasing crop yields (Ghooshchi et al., 2008). Improving the effectiveness of water application and optimum use of water source as one of the main axis of stable agriculture in dry and semi-dry regions is necessary. Super absorbent materials (SAMs) are hydrophilic polymer complexes that have potential to absorb large volumes of aqueous fluids within a short time and under stress conditions can hold the absorbed water (Akbal, 2004.). Super absorbent polymers may have great potential in restoration and reclamation of soil and storing water available for plant growth and production (Zhang et al., 2007). According to this basis, one of the ways to increase the water supply in soil is applying super absorbent polymers that supply water for crop roots (Pawlowski et al., 2009). Super absorbents are able to absorb and store water hundreds times of their dry weight (Abedi-Koupai and Asadkazemi, 2006). These polymers enhance the biological condition in water deficit stress by increasing the capacity of water storage in soil, reduction of wasting water and nutrition materials of soil (Sarvas et al., 2007). The application of super absorbent polymers has a significant impact in reducing drought stress effects and to improve 
plant yield and stability in agriculture production (Khadem et al., 2010.). The aim of this study was to evaluate the effect of five amounts of super absorbent materials $(0,1,2,3,4$ and $5 \mathrm{~g} / \mathrm{kg}$ soil) and three levels of drought stress treatments (irrigation at $25 \mathrm{~mm}, 50 \mathrm{~mm}$ and $75 \mathrm{~mm}$ evaporation from pan class A) on yield and yield components of Brassica napus $\mathrm{L}$.

\section{Materials and methods}

To evaluate effects of super absorbent polymer under different irrigation regimes on the yield and yield components of Brassica napus L., a factorial experiment was conducted based on randomized complete block design with four replicas, in year 2010. Treatments included super absorbents $(0,1,2,3,4$ and $5 \mathrm{~g} / \mathrm{kg}$ soil $)$ and drought stress (irrigation at $25 \mathrm{~mm}, 50 \mathrm{~mm}$ and $75 \mathrm{~mm}$ evaporation from class A pan). The experiment was conducted in pots with 5 $\mathrm{kg}$ of soil. From each plot five plants were harvested to determine the yield of seed. The following measurements were recorded from each of the plants: stem length $(\mathrm{cm})$, stem diameter $(\mathrm{mm})$, stem weight $(\mathrm{g})$, the number of seeds per sheath, number of seeds per plant, seed weight per sheath $(\mathrm{g})$ and seed weight per plant $(\mathrm{g})$.

The dry weight was recorded after drying of samples in an oven at $70^{\circ} \mathrm{C}$ for $72 \mathrm{~h}$. Seed and sheath were separated from leaves and stems before all plant parts were oven-dried at $70^{\circ} \mathrm{C}$. At the end of growth stage, Soxhlet extraction was employed to determine the total oil concentration of the canola seed. In the Soxhlet procedure, $10 \mathrm{~g}$ of milled seeds were packed in a paper extraction thimble and oil was extracted by using $300 \mathrm{ml}$ of petroleum benzene in a Soxhlet extractor, for 4 hours, and the solvent was then evaporated. Oils were filtered and dehydrated by using Whatman filters. Finally, oil content was determined by the following formula (Metcalf et al., 1996):

\section{Oil yield $=$ Oil percentage $\times$ Seed yield}

Analysis of variance (ANOVA) on data was performed using the general linear model (GLM) procedure in the SAS 9.1 software. The Student-Newman Keul's test (SNK) was applied to compare treatment means using the MSTATC software.

Tab. 1. Analysis of variance of super absorbent polymer and irrigation effects on the yield and yield components of Brassica napus $\mathrm{L}$.

\begin{tabular}{|c|c|c|c|c|c|c|c|c|c|}
\hline $\begin{array}{l}\text { Source of } \\
\text { Variation }\end{array}$ & $\mathrm{df}$ & Stem length & Stem width & $\begin{array}{l}\text { Stem } \\
\text { weight }\end{array}$ & $\begin{array}{l}\text { Number of } \\
\text { seeds per } \\
\text { sheath }\end{array}$ & $\begin{array}{l}\text { Number of } \\
\text { Seeds per plant }\end{array}$ & $\begin{array}{l}\text { Fertile } \\
\text { sheath }\end{array}$ & $\begin{array}{l}\text { Fertile sheath } \\
\text { percent }\end{array}$ & Sterile sheath \\
\hline Replication & 51 & 5.07 & 0.005 & 0.034 & 7.97 & 1092.9 & 12.40 & 215.63 & 0.56 \\
\hline Super absorbent & 5 & 23.06 & 0.003 & 0.11 & 8.28 & $12774.8^{* *}$ & $16.35^{*}$ & $382.11^{* *}$ & $1.76^{* *}$ \\
\hline Irrigation regime & 2 & 13.46 & $0.012^{* *}$ & $0.40^{* *}$ & $27.15^{*}$ & 4479.01 & 2.52 & $839.24^{* *}$ & $22.81^{* *}$ \\
\hline $\begin{array}{l}\text { Super absorbent } \\
\times \text { Irrigation regime }\end{array}$ & 10 & $30.37^{*}$ & $0.008^{* *}$ & $0.18^{* *}$ & $20.94^{* *}$ & $15988.4^{* *}$ & $96.07^{* *}$ & $313.94^{* *}$ & $1.75^{* *}$ \\
\hline Error & 71 & 14.58 & 0.002 & 0.05 & 7.31 & 2722.2 & 6.78 & 89.23 & 0.16 \\
\hline Coefficient of variation & (\%) & 10.21 & 18.04 & 28.09 & 21.02 & 25.41 & 16.28 & 10.34 & 30.82 \\
\hline
\end{tabular}

Continue Tab. 1.

\begin{tabular}{cccccccc}
\hline $\begin{array}{c}\text { Source of } \\
\text { Variation }\end{array}$ & df & $\begin{array}{c}\text { Sheath } \\
\text { Total(Sterile+ } \\
\text { Fertile) }\end{array}$ & 1000 seed weight & $\begin{array}{c}\text { Seed weight per } \\
\text { plant }\end{array}$ & $\begin{array}{c}\text { Sheath } \\
\text { length }\end{array}$ & $\begin{array}{c}\text { Sheath weight per } \\
\text { plant }\end{array}$ & $\begin{array}{c}\text { Oil } \\
\text { percent }\end{array}$ \\
\hline Replication & 10 & 0.92 & 0.62 & 0.001 & 0.027 & 0.065 & 28.9 \\
Super absorbent & 51 & $120.72^{* *}$ & $10.49^{* *}$ & $0.14^{* *}$ & $0.42^{*}$ & $6.44^{* *}$ & $1.88^{*}$ \\
\hline $\begin{array}{c}\text { Irrigation regime } \\
\text { Super absorbent } \times \text { Irrigation } \\
\text { regime }\end{array}$ & 5 & $124.22^{* *}$ & $14.52^{* *}$ & $0.32^{* *}$ & $0.73^{* *}$ & $5.13^{* *}$ & 5.28 \\
Error & 71 & $75.68^{* *}$ & $7.68^{* *}$ & $0.21^{* *}$ & 0.24 & $8.10^{* *}$ & $6.99^{* *}$ \\
Coefficient of variation (\%) & 9.15 & 0.95 & 0.017 & 0.14 & 0.14 & 3.1 \\
\hline
\end{tabular}

\section{Results and discussion}

Interaction effects between super absorbent polymers and irrigation regimes on the stem length, stem width, stem weight, the number of seeds per sheath, the numbers of seeds per plant, number of fertile sheath per plant, fertile sheath percent, the number of sterile and total sheath, 1000 seeds weight, seed weight per plant, sheath weight per plant and oil percentage of seed were significant for $(\mathrm{p} \leq 0.01)$, too $(\mathrm{p} \leq 0.01)$ (Tab. 1). Results from ANOVA analysis shows significant effect of super absorbents $(\mathrm{p} \leq 0.05)$ and drought stress $(p \leq 0.01)$ on the sheath length.
Means comparison indicated that the longest sheath $(5.01 \mathrm{~cm})$ was obtained from control treatment, and the shortest sheath $(4.45 \mathrm{~cm})$ belonged to $1 \mathrm{~g}$ super absorbent polymer/ kg soil (Fig. 1). The use of $3 \mathrm{~g}$ polymer/kg soil produced the same sheath length as the application of $1 \mathrm{~g}$ polymer $/ \mathrm{kg}$ soil. All treatments with super absorbent polymer produced shorter stems than control (Fig. 1-I). In irrigation treatments, the longest sheath $(4.9 \mathrm{~cm})$ was obtained from irrigation level at $25 \mathrm{~mm}$ evaporation from pan, while the shortest sheath $(4.56 \mathrm{~cm})$ belonged to irrigation at $75 \mathrm{~mm}$ evaporation. Increasing irrigation intervals from 25 to $75 \mathrm{~mm}$ evaporation caused shorten sheath, significantly different (Fig. 1-II). 
I

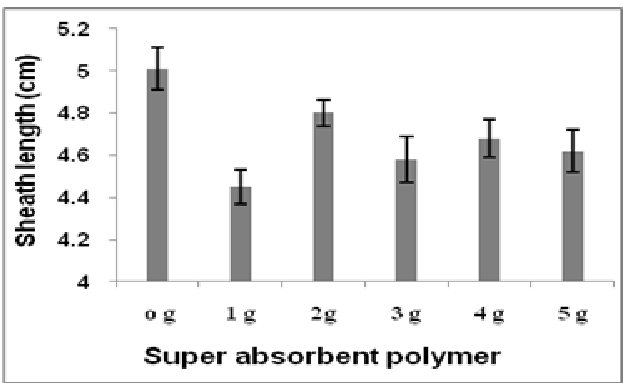

II

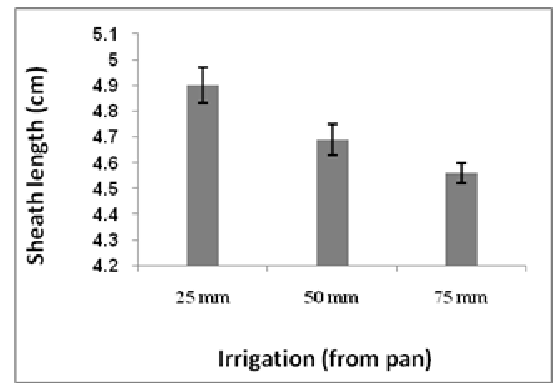

Fig. 1. Means comparison of sheath length of Brassica napus L. treated with varying amounts of super absorbent (I) under different Irrigation regimes (II). The same letters show non-significant differences

Means comparison indicated that the longest stem $(42.37 \mathrm{~cm})$ was obtained from plants treated by $2 \mathrm{~g}$ polymer $/ \mathrm{kg}$ soil and irrigation at $75 \mathrm{~mm}$ evaporation from pan. while the shortest stem $(33.1 \mathrm{~cm})$ belonged to plants treated with $4 \mathrm{~g}$ polymer $/ \mathrm{kg}$ soil and irrigation at $50 \mathrm{~mm}$ evaporation from class A pan, and irrigation at $50 \mathrm{~mm}$ evaporation and $5 \mathrm{~g}$ polymer/kg soil (Fig. 1-II, Fig. 2-I). The obtained results show an ascending trend in stem length along with super absorbent polymers increase, in all irrigation regimes. Application of $2 \mathrm{~g}$ super absorbent polymers produced the highest stem length of Brassica napus in all irrigation regimes levels.
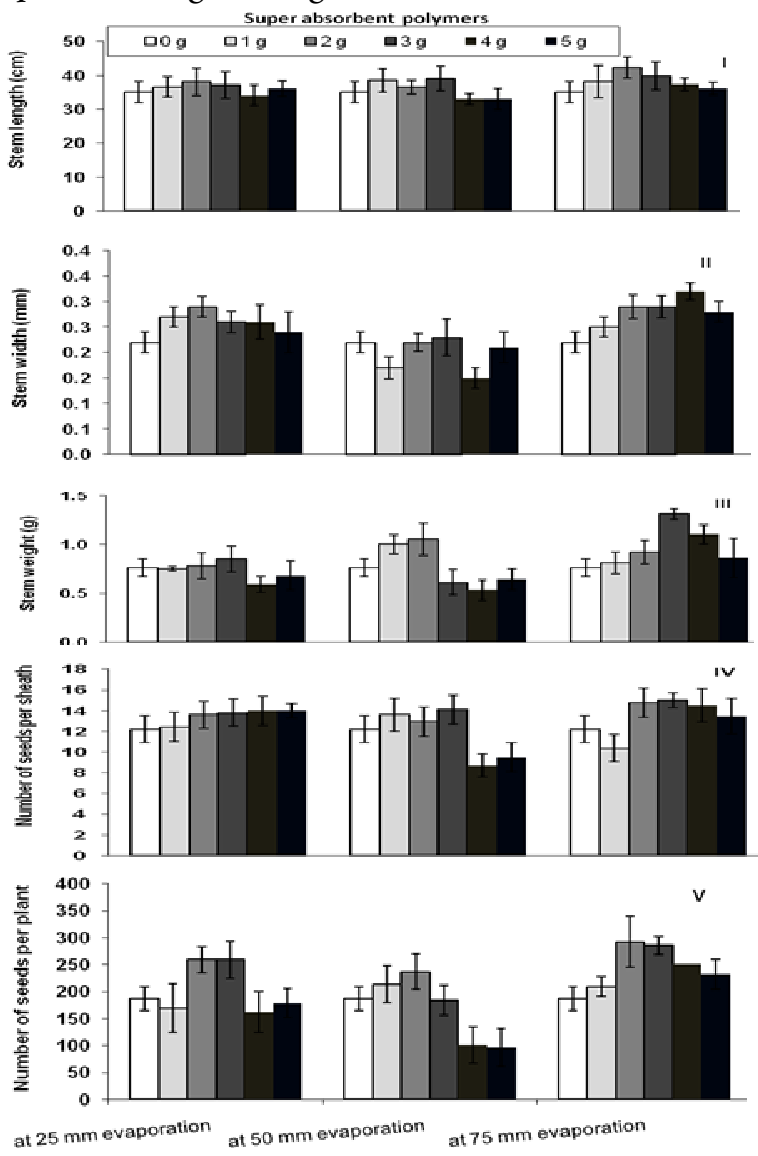

Fig. 2. Means comparisons of stem length (I), stem width (II), stem weight (III), number of seeds per sheath (IV) and number of seeds per plant $(\mathrm{V})$ at different levels of super absorbent polymer and drought stress

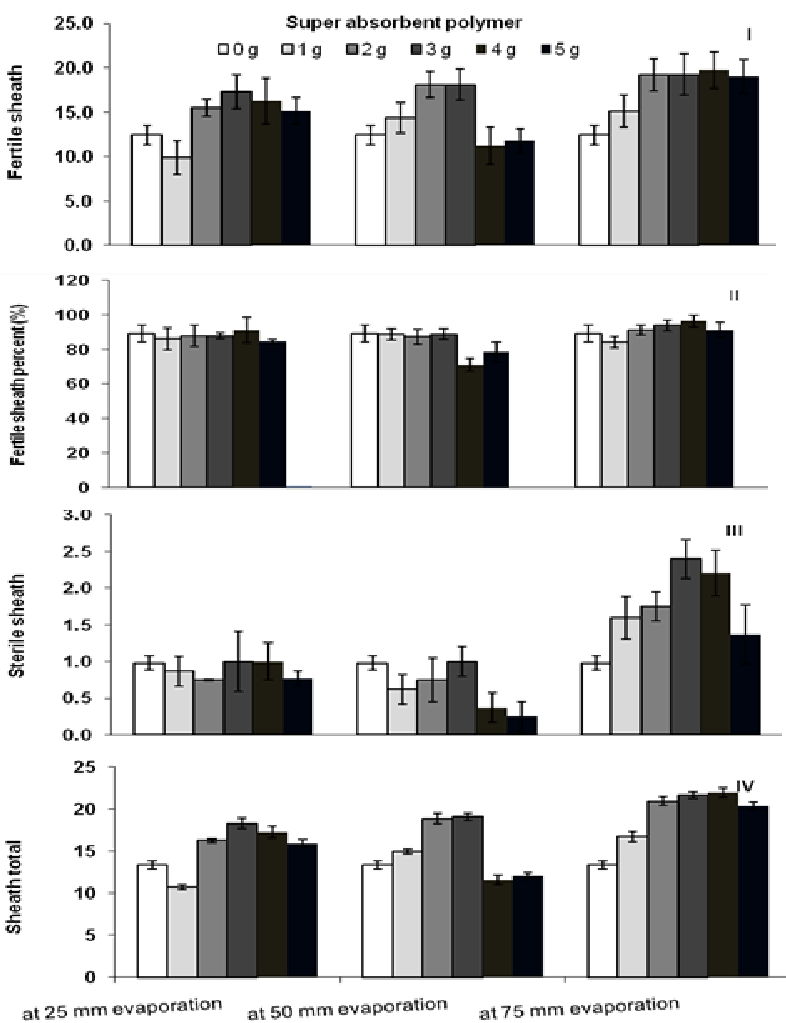

Fig. 3. Means comparisons of fertile sheath (I), fertile sheath percent (II), Sterile sheath (III) and sheath total (IV) at different levels of super absorbent polymer and drought stress

The maximum stem width $(3.2 \mathrm{~mm})$ was observed at plants treated by $4 \mathrm{~g}$ polymer $/ \mathrm{kg}$ soil and irrigation at 75 $\mathrm{mm}$ evaporation (Fig. 1-II, Fig. 2-II). The minimum stem width $(1.7 \mathrm{~mm})$ belonged to $4 \mathrm{~g}$ polymer $/ \mathrm{kg}$ soil and irrigation at $50 \mathrm{~mm}$ evaporation likewise the irrigation at 50 $\mathrm{mm}$ evaporation and using 1 and $5 \mathrm{~g}$ polymer $/ \mathrm{kg}$ soil (Fig. 2-II).

The highest stem weight $(1.31 \mathrm{~g})$ belonged to $3 \mathrm{~g}$ polymer $/ \mathrm{kg}$ soil treatment and irrigation at $75 \mathrm{~mm}$ evaporation from pan. The lowest stem weight $(0.53 \mathrm{~g})$ was obtained from plants treated by $4 \mathrm{~g}$ polymer $/ \mathrm{kg}$ soil under irrigation at $50 \mathrm{~mm}$ evaporation, such as the stem weight of irrigation at $50 \mathrm{~mm}$ evaporation from pan and using 3 and 5 g polymer/kg soil (Fig. 3-III). 
The highest number of seeds per sheath (15.02) was obtained from using $3 \mathrm{~g} / \mathrm{kg}$ soil of polymer and irrigation at $75 \mathrm{~mm}$ evaporation from pan, that similar irrigation after 75 $\mathrm{mm}$ evaporation from pan and by using 2 and $4 \mathrm{~g} / \mathrm{kg}$ soil of polymer. The lowest number of seeds per sheath (8.7) belonged to $4 \mathrm{~g} / \mathrm{kg}$ soil of polymer and irrigation at $50 \mathrm{~mm}$ evaporation from pan, similar with application $5 \mathrm{~g} / \mathrm{kg}$ soil of polymer and irrigation at $50 \mathrm{~mm}$ evaporation from pan (Fig. 2-IV).

The highest number of seeds per plant (292.4) was obtained from $2 \mathrm{~g}$ polymer $/ \mathrm{kg}$ soil and irrigation at $75 \mathrm{~mm}$ evaporation from pan, similar with $3 \mathrm{~g}$ polymer $/ \mathrm{kg}$ soil and irrigation at $75 \mathrm{~mm}$ evaporation from pan. The lowest number seed per plant (96.7) belonged to plants treated by $4 \mathrm{~g}$ polymer $/ \mathrm{kg}$ soil and irrigated at $50 \mathrm{~mm}$ evaporation from pan, such as using $5 \mathrm{~g}$ polymer $/ \mathrm{kg}$ soil and irrigation at $50 \mathrm{~mm}$ evaporation from pan. The same trends of stem length, here we obtained ascending trend in number of seeds per plant along with super absorbent polymer increase, in all irrigation regimes. Application of $2 \mathrm{~g}$ of super absorbent polymers produced the highest number of seeds per plant of Brassica napus in irrigation regime levels.

The maximum number of fertile sheath (19.7) belonged to irrigation at $75 \mathrm{~mm}$ evaporation from pan and using $4 \mathrm{~g}$ polymer $/ \mathrm{kg}$ soil as same as using 2 and $3 \mathrm{~g}$ polymer $/ \mathrm{kg}$ soil along with irrigation at $50 \mathrm{~mm}$ evaporation. The minimum number of fertile sheath per plant (11.18) belonged to irrigation at $50 \mathrm{~mm}$ evaporation and using $4 \mathrm{~g}$ polymer $/ \mathrm{kg}$ soil, likewise in case of the application of $5 \mathrm{~g}$ polymer $/ \mathrm{kg}$ soil in this above irrigation regime. Results showed ascending trend in fertile sheath along with super absorbent polymer increase, in all irrigation regimes (Fig. 3-I).

Like fertile sheath number, the maximum fertile sheath percent (96.4\%) belonged to irrigation at $75 \mathrm{~mm}$ evaporation from pan and using $4 \mathrm{~g}$ polymer $/ \mathrm{kg}$ soil as same as using 2 and $3 \mathrm{~g}$ polymer $/ \mathrm{kg}$ soil along with irrigation at 50 $\mathrm{mm}$ evaporation. The minimum fertile sheath percent (71.3\%) belonged to irrigation at $50 \mathrm{~mm}$ evaporation and using $4 \mathrm{~g}$ polymer $/ \mathrm{kg}$ soil as same as $5 \mathrm{~g}$ polymer $/ \mathrm{kg}$ soil in this irrigation (Fig. 3-II).

The maximum number of sterile sheath (2.4) was occurred at $3 \mathrm{~g}$ polymer $/ \mathrm{kg}$ soil and irrigation at $75 \mathrm{~mm}$ evaporation from pan, that it was the same with $4 \mathrm{~g}$ polymer $/ \mathrm{kg}$ soil and irrigation at $75 \mathrm{~mm}$ evaporation from pan. The minimum number of sterile sheath (0.25) belonged to irrigation at $50 \mathrm{~mm}$ evaporation from pan and by using $5 \mathrm{~g} / \mathrm{kg}$ soil of polymer, that similar by $4 \mathrm{~g}$ polymer $/ \mathrm{kg}$ soil and irrigation at $50 \mathrm{~mm}$ evaporation (Fig. 3-III).

The maximum number of total sheath per plant (21.95) was obtained from irrigation at $75 \mathrm{~mm}$ evaporation from pan and using $4 \mathrm{~g}$ polymer $/ \mathrm{kg}$ soil, such as with 2 and $3 \mathrm{~g} / \mathrm{kg}$ and irrigation at $75 \mathrm{~mm}$ evaporation. The minimum number of total sheath (11.59) belonged to the usage of $4 \mathrm{~g}$ polymer $/ \mathrm{kg}$ soil irrigated at $50 \mathrm{~mm}$ evaporation from pan, similar to $5 \mathrm{~g}$ polymer $/ \mathrm{kg}$ soil and irrigation at $50 \mathrm{~mm}$ evaporation. Here we obtained ascending trend in sheath total along with super absorbent polymer increase, in all irrigation regimes, the sheath total at $5 \mathrm{~g}$ of polymer showed a decline in comparison with others (Fig. 3-IV).

The greatest 1000 seeds weight $(6.55 \mathrm{~g})$ belonged to plants treated with $2 \mathrm{~g}$ polymer/ $\mathrm{kg}$ soil and irrigated at 75 $\mathrm{mm}$ evaporation from pan. And the lowest amounts of
1000 seeds weight $(1.74 \mathrm{~g})$ was obtained from plants treated by $4 \mathrm{~g}$ polymer $/ \mathrm{kg}$ soil and irrigation at $50 \mathrm{~mm}$ evaporation from pan, that it had no different with application of $3 \mathrm{~g}$ polymer/kg soil in this irrigation (Fig. 4-I).

The greatest seed weight per plant $(1.1 \mathrm{~g})$ belonged to plants treated with $3 \mathrm{~g}$ polymer $/ \mathrm{kg}$ soil and irrigation at 75 $\mathrm{mm}$ evaporation from pan. It had no different with 2 and 4 g polymer $/ \mathrm{kg}$ soil irrigated at $75 \mathrm{~mm}$ evaporation from pan. The lowest amounts of seed weight per plant $(0.3 \mathrm{~g})$ was observed in plants treated by $4 \mathrm{~g}$ polymer $/ \mathrm{kg}$ soil and irrigated at $50 \mathrm{~mm}$ evaporation as same as seed weight of using $5 \mathrm{~g}$ polymer $/ \mathrm{kg}$ soil and irrigation at $50 \mathrm{~mm}$ evaporation from pan (Fig. 4-II).

The maximum sheath weight per plant $(2.78 \mathrm{~g})$ belonged to $2 \mathrm{~g}$ polymer $/ \mathrm{kg}$ soil and irrigation at $75 \mathrm{~mm}$ evaporation, that it was similar to 3 and $4 \mathrm{~g}$ polymer $/ \mathrm{kg}$ soil and irrigation at $75 \mathrm{~mm}$ evaporation. The minimum sheath weight per plant $(0.57 \mathrm{~g})$ belonged to $4 \mathrm{~g}$ polymer $/ \mathrm{kg}$ soil and irrigation at $50 \mathrm{~mm}$ evaporation, same with $5 \mathrm{~g}$ polymer $/ \mathrm{kg}$ soil and irrigation at $50 \mathrm{~mm}$ evaporation (Fig. 4-III).

The maximum percentage of seed oil (34.8\%) belonged

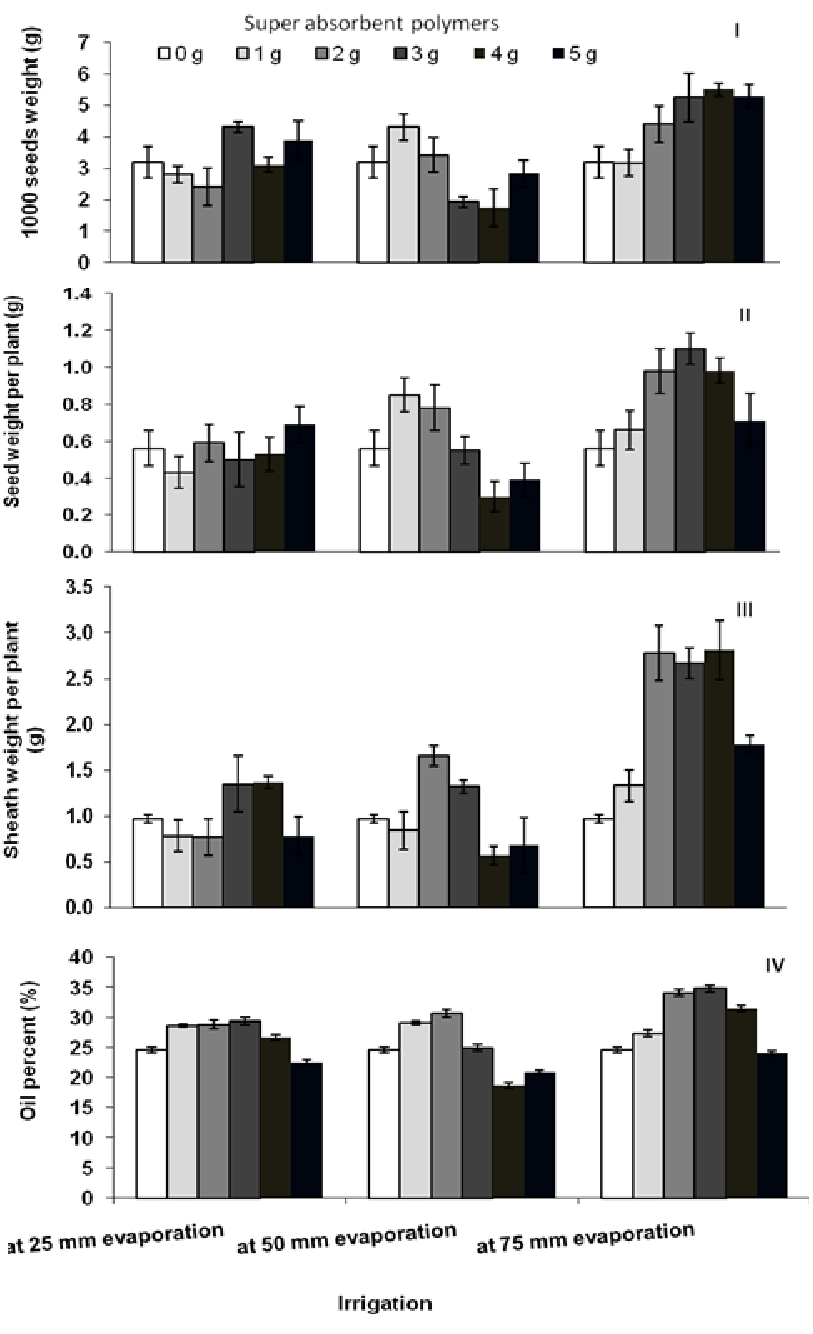

Fig. 4. Means comparisons of sheath on 1000 seeds weight (I), seed weight per plant (II), sheath weight per plant (III) and oil percent (IV) at different levels of super absorbent polymer and drought stress 
372

to plants treated by $3 \mathrm{~g}$ polymer $/ \mathrm{kg}$ soil and irrigation at 75 $\mathrm{mm}$ evaporation from pan, that it was the same with oil percent of 2 and $4 \mathrm{~g}$ polymer $/ \mathrm{kg}$ soil and irrigation at 75 $\mathrm{mm}$ evaporation. The minimum percentage of seed oil (18.7\%) was obtained from $4 \mathrm{~g}$ polymer $/ \mathrm{kg}$ soil and irrigation at $50 \mathrm{~mm}$ evaporation from pan, that it was similar to $5 \mathrm{~g}$ polymer $/ \mathrm{kg}$ soil in this irrigation. Despite of increasing oil percent in the lower polymer treatments, the oil percentage of 4 and $5 \mathrm{~g}$ polymer $/ \mathrm{kg}$ soil was declined rather than 2 and 3 g polymer/kg soil (Fig. 4-IV).

\section{Discussion}

Super absorbent polymers are able to store water in an effective way and under stress condition gives it to the plant. These materials prevent water and nutrition materials leaching, therefore increase the yield of the plant (TohidiMoghadam et al., 2009). Abraham and Rajasekharan Pillai (1995) reported that hydrophilic polymers application significantly reduced the amount of ammonium leaching from the soil structure. Researches from Yazdani et al. (2007) on soybean showed that application of super absorbent polymers under drought stress increased grain yield and the total dry weight of soybean plants. The application of super absorbent polymers has a significant impact in reducing drought stress effects and to improve plant yield and stability in agriculture production (Khadem et al., 2010). Khadem et al. (2010) also showed that adding super absorbent polymers can linearly increase 1000-seed weight of corn and soybean crops, respectively. Hayat and Ali (2004) also found that polymer effect on yield parameters helps the increase crop yield.

Razmjoo et al. (2008) and Baghalian et al. (2011) reported that drought stress caused a significant reduction in plant height, stem weight and flower yield of Matricaria chamomilla. Moreover, drought stress significantly reduces the plant height, stem dry weight, flower diameter, flower fresh and dry weight in marigold based on reports of AbdulWasea and Khalid (2010). Singh and Ramesh (2000) also reported that water deficit stress reduced the oil yield of rosemary on a hectare basis, but oil yield on a plant fresh weight basis did not appear to be affected. Baghalian et al. (2011) reported that drought stress caused a significant reduction in yield of Matricaria chamomilla. Afsharmanesh (2009) stated the significant effect of drought stress on reduction of fresh and dry weight in sorghum and alfalfa. Drought stress lead to weak transfer of mineral nutrient from soil to plant (Hopkins, 2004) and causes significant reduction in dry weight in comparison with control plants (Iqbal et al., 2005.). Moazen Ghamsari et al. (2009) also reported the increase in function with application of 300 and $200 \mathrm{~kg}$ super absorbent in hectare. Probably using super absorbent caused to increase in number and weight of 1000seeds that cause increase in function of the seed in mentioned attendance. Nazarli et al. (2010) reported high 100 -seed weight, resulting from more irrigation, was probably due to the availability of adequate soil moisture and assimilates from source to sink seed formation and seed ripping stages. Application of polymer tended to increase 100 -seed weight of sunflower compared to the control (without polymer).

\section{Conclusions}

The greatest 1000 seeds weight $(6.55 \mathrm{~g})$ and the maximum numbers of total sheath per plant (20.25) were observed at plants treated by $3 \mathrm{~g}$ polymer $/ \mathrm{kg}$ soil and irrigation at $75 \mathrm{~mm}$ evaporation. The maximum number of fertile sheath (19.7) and the highest fertile sheath percentage (96.4\%) belonged to $4 \mathrm{~g}$ polymer $/ \mathrm{kg}$ soil and irrigation at 75 $\mathrm{mm}$ evaporation. The minimum 1000 seeds weight $(1.74 \mathrm{~g})$, the number of total (11.5), fertile sheath (11.18) and fertile sheath percentage $(71.3 \%)$ was correlated with the irrigation at $50 \mathrm{~mm}$ evaporation at application of $4 \mathrm{~g}$ of polymer $/ \mathrm{kg}$ soil. The maximum oil percentage $(34.8 \%)$ resulted at the treatment using $3 \mathrm{~g}$ polymer $/ \mathrm{kg}$ soil and irrigation at $75 \mathrm{~mm}$ evaporation from pan.

\section{References}

Abdul- Wasea AA, Khalid ME (2010). Alleviation of drought stress of marigold plants by using arbuscular mycorrhizal fungi. Saudi J Biol Sci 18(1):93-98.

Abedi T, Pakniyat H (2010). Antioxidant enzyme changes in response to drought stress in ten cultivars of Oilseed rape (Brassica napus L.). Czech J Genet Plant Breed 46(1):27-34.

Abedi-Koupai J, Asadkazemi J (2006). Effects of a hydrophilic polymer on the field soil, the performance of an ornamental plant (Cupressus arizonica) under reduced irrigation regimes. Iran Polym J 15(9): 715-725.

Abraham J, Rajasekharan Pillai VN (1995). N, N-methylene bisacrylamide-crosslinked polyacrylamide for controlled release urea fertilizer formulations. Commun Soil Sci Plant Anal 26(19-20): 3231-3241.

Afsharmanesh G (2009). Study of some morphological traits and selection of drought resistant alfalfa cultivars (Medicago sativa L.) in Jiroft, Iran. Plant Ecophysiol 3:109118.

Akbal F (2004). Sorption of phenol and 4-chlorophenol onto Pumice treated with cationic surfactant. J Environ Manag 74(3):239-244.

Baghalian K, Abdoshah Sh, Khalighi-Sigaroodi F, Paknejad F (2011). Physiological and phytochemical response to drought stress of German chamomile (Matricaria recutita L.). Plant Physiol Biochem 49:201-207.

Din J, Khan SU, Ali I, Gurmani AR (2011). Physiological and agronomic responses of canola varieties to drought stress. J Anim Plant Sci 21(1):78-82.

Ghooshchi F, Seilsepour M, Jafari P (2008). Effects of water stress on yield and some agronomic traits of maize (SC 301). Am-Eurasian J Agric Environ Sci 4(3):302-305.

Hayat R, Ali S (2004). Water absorption by synthetic polymer (Aquasorb) and its effect on soil properties and tomato yield. Int J Agric Biol 6(6):998-1002.

Hopkins WG (2004). Introduction to plant physiology (3rd ed.). John Wiley and Sons. New York, PP. 557. 
Iqbal N, Ashraf MY, Ashraf M (2005). Influence of water stress and exogenous glycinebetaine on sunflower achene weight and oil percentage. Int J Environ Sci Technol 2(2):155-160.

Jensen CR, Mogensen VO, Mortensen G, Fieldsend JK, Milford GFJ, Anderson M N, Thage JH (1996). Seed glucosinolate, oil and protein content of field-grown rape (Brassica napus L.) affected by soil drying and evaporative demand. Field Crop Res 47(2-3):93-105.

Khadem SA, Galavi M, Ramrodi M, Mousavi SR, Rousta MJ, Rezvani-Moghadam P (2010). Effect of animal manure and super absorbent polymer on corn leaf relative water content, cell membrane stability and leaf chlorophyll content under dry condition. Aust J Crop Sci 4(8):642647.

Metcalf LC, Schmitz AA, Pelka JR (1996). Rapid preparation of fatty acid esters from lipids for gas chromatographic analysis. Anal Chem 38(3):514-515.

Moazen Ghamsari B, Akbari AG, Zohourian MJ, Nikniaei AB (2009). Evaluation of growth and yield of forage corn with application of different levels of super absorbent polymer (A200) under drought stress 40(3): 1-8.

Nazarli H, Zardashti MR, Darvishzadeh R, Najafi S (2010). The effect of water stress and polymer on water use efficiency, yield and several morphological traits on sunflower. Not Sci Biol 2(4):53-58.

Ohashi Y, Nakayama N, Saneoka H, Fujita K (2006). Effects of drought stress on photosynthetic gas exchange, chlorophyll fluorescence and stem diameter of soybean plants. Biol Plantarum 50(1):138-141.

Pawlowski A, Lejcus K, Garlikowski D, Orezesyna H (2009). Geocomposite with superabsorbent as an element improving water availability for plants on slopes. Geophys Res Abstr 11:1-2.
Razmjoo K, Heydarizadeh P, Sabzalian MR (2008). Effect of salinity and drought stresses on growth parameters and essential oil content of Matricaria chamomila. Int J Agric Biol 10(4):451-454.

Sarvas M, Pavlenda P, Takacova E (2007). Effect of hydrogel application on survival and growth of pine grainling in reclamations. J For Sci 53(5):204-209.

Singh M, Ramesh S (2000). Effect of irrigation and nitrogen on herbage, oil yield and water-use efficiency in rosemary grown under semi-arid tropical conditions. J Med Arom Plant Sci 22(1B):659-662.

Tohidi-Moghadam HR, Shirani-Rad AH, Nour-Mohammadi G, Habibi D, Modarres-Sanavy SAM, Mashhadi-AkbarBoojar M, Dolatabadian A (2009). Response of six oilseed rape genotypes to water stress and hydrogel application. Agropec Trop Goiania 39(3):243-250.

Yazdani F, Allahdadi I, Akbari GA (2007). Impact of super absorbent polymer on yield and growth analysis of soybean (Glycine max L.) under drought stress condition. Pak J Biol Sci 10(23):4190-4196.

Zahedi H, Noormohammadi G, Shirani-Rad AH, Habibi D, Mashhadi-Akbar-Boojar M (2009). The effects of zeolite and foliar applications of selenium on growth, yield and yield components of three canola cultivars under drought stress. World Appl Sci J 7(2):255-262.

Zhang PF, Avudzega DM, Bowman RS (2007). Removal of perchlorate from contaminated waters using surfactantmodified zeolite. J Environ Qual 36(4):1069-1075. 